\title{
Health risk behaviours of Palestinian youth: findings from a representative survey
}

Peter Glick, ${ }_{1}^{1}$ Umaiyeh Al-Khammash, ${ }^{2,3}$ Mohammed Shaheen, ${ }^{4}$ Ryan Brown, ${ }^{1}$ Prodyumna Goutam, ${ }^{1}$ Rita Karam, ${ }^{1}$ Sebastian Linnemayr ${ }^{1}$ and Salwa Massad ${ }^{3,5}$

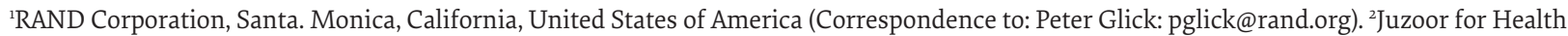
and Social Development, Ramallah, West Bank. ${ }^{3}$ United Nations Relief and Works Agency for Palestine Refugees in the Near East (UNRWA), East Jerusalem, Palestine. ${ }^{4}$ Al Quds University, Abu-Dis, West Bank. ${ }^{5}$ Palestinian National Institute of Public Health, West Bank.

\begin{abstract}
Background: There is little systematic information about health risk behaviours among youth in Middle Eastern countries, leaving public health authorities unprepared to deal with emerging public health threats at a time of major social change.

Aim: The Palestinian Youth Health Risk study investigates patterns of risk behaviours among Palestinian youth, their perceptions of the risks and benefits of such behaviours, and the relationship of exposure to violence with mental health and engagement in risk behaviours.

Methods: We conducted a representative survey among 2500 individuals aged 15-24 years in the West Bank and East Jerusalem, permitting reliable comparison across sex and rural-urban divisions. A stratified 2-stage random sample was drawn from the 2007 population census, with strata formed by crossing the 12 governorates with urban, rural and refugee camp locations. Within strata, 208 survey clusters were sampled with probability proportional to size. Within each cluster, 14 households with youth of the appropriate age were sampled.
\end{abstract}

Results: Among youth aged 20-24 years, $22.4 \%$ of males and $11.6 \%$ of females reported trying alcohol; $10.5 \%$ of males and $4.3 \%$ of females reported trying drugs. Almost one quarter of unmarried youth aged 20-24 years reported any sexual experience. Tobacco use is high, even among younger youth ( $45.4 \%$ of males and $21.2 \%$ of females aged $15-19$ smoke). Risk behaviours are higher among males, older youth and in urban areas and refugee camps.

Conclusion: While smoking is of particular concern, prevention outreach for all behaviours should be directed at subgroups and areas identified as highest risk.

Keywords: youth, health risk behaviours, Palestine, survey

Citation: Glick P; Khammash U; Shaheen M; Brown R; Goutam P; Karam R; et al. Health risk behaviours of Palestinian youth: findings from a representative survey. East Mediterr Health J. 2018;24(2):127-136. https://doi.org/10.26719/2018.24.2.127.

Received: 27/06/16; accepted: 15/05/17

Copyright (C) World Health Organization (WHO) 2018. Some rights reserved. This work is available under the CC BY-NC-SA 3.0 IGO license (https:// creativecommons.org/licenses/by-nc-sa/3.o/igo).

\section{Introduction}

Relatively little is known about key health risk behaviours among youth in the Middle East and North Africa (MENA), leaving public health authorities in the region unprepared to deal with emerging public health threats at a time of major social changes. Rates of tobacco use among younger adolescents aged 13-15 years, for whom systematic data are available, are higher in the MENA region than in other regions other than Latin America and the Caribbean (1). Although youth-specific data are lacking, the use of injecting drugs has been noted in many countries, including Lebanon, Libya, Morocco, Oman, Saudi Arabia and Tunisia (2), and there is evidence of significant recent increases in the use of amphetamines, opioids and other drugs, particularly in the countries bordering the Persian Gulf (3). With regard to sexual activity among youth, a rising age of marriage throughout the region as well as increases in rates of sexually transmitted infections $(2,4)$ suggest increasing rates of sexual activity outside of (and before) marriage. In Morocco, $40 \%$ of reported sexually transmitted infections are among 15-29-year-olds (5).

Youth in the occupied Palestinian territory of the West Bank, East Jerusalem and Gaza are experiencing similar risks, including particularly high rates of tobacco use $(6,7)$. Drug use, especially in East Jerusalem, is a growing concern (8). Youth unemployment, considered a risk factor for drug use $(9,10)$, is very high $(26 \%$ and $55 \%$ in the West Bank and Gaza, respectively, for those aged 20-24 years) (11). A further potential risk factor facing Palestinian youth is the stress of sustained political conflict and economic hardship. An understanding of the patterns and causes of youth health risk behaviours will enable policymakers to develop and target appropriate prevention programmes (12).

Existing studies of youth in the occupied Palestinian territory and the region have serious drawbacks that limit our understanding of the prevalence and patterns of most risk behaviours. These studies mostly use schoolbased samples of adolescents rather than representative, random samples of youth that include out of school and older youth, who may be at greatest risk. Existing surveys 
also typically do not cover many key risk behaviours (in particular sensitive behaviours such as sexual activity), or do so only in terms of perceptions regarding peers, not the youth's own engagement.

The Palestinian Youth Health Risk Study addresses this gap and to our knowledge is the first in the region to collect large scale, representative data on risk behaviours among youth including smoking, alcohol and drug use, sexual activity and interpersonal violence. The study was designed to investigate levels and patterns of these behaviours as well as mental health among Palestinian youth, youths' perceptions of the risks and benefits of such behaviours and their expectations about the future, and the relationship of exposure to violence and conflict to mental health, future orientation and engagement in risk behaviours. This paper presents findings on the prevalence of risk behaviours among youth aged 15-24 years, considering variations by sex, age and location. Location is a potentially important determinant given the differences between rural and urban areas of the occupied Palestinian territory-and between them and refugee camps-with respect to cultural attitudes, access to alcohol and drugs, and economic and political tensions.

\section{Methods}

\section{Study population and sampling}

The survey targeted a representative sample of 2500 youth aged 15-24 years in the West Bank and East Jerusalem, reflecting the objective of permitting reliable comparisons across sex and rural-urban divisions. A stratified 2-stage random sample was drawn from the 2007 population census, with strata formed by crossing the 12 governorates with urban, rural and refugee camp location. Within strata, 208 survey clusters (census enumeration areas) were randomly sampled with probability proportional to size. Within each cluster, 14 households with youth in the appropriate age range were sampled using a modified random walk. Implicit stratification ensured equal numbers of male and female youths. Where households had multiple youth, the participant was selected using Kish tables (13). Data collection took place during March-June 2014.

Extensive formative research, including focus groups and in-depth interviews with youth as well as thorough pre-testing of survey questions, was used to determine culturally appropriate approaches to interviewing and question wording, sequence and response formats. The survey asked questions on a range of other topics before coming to sensitive issues about behaviours, and asked first about behaviours of general peers and close friends of the respondent before asking about their own activities. Substantial efforts were made to develop procedures to ensure that youth were comfortable discussing sensitive topics. Interviewers were strictly instructed to ensure that the youth interview was conducted in a private room or other private area (e.g. the roof of the house). Youth could choose to be interviewed at a local youth centre or other outside location, though few did so. Interviewers were matched to respondents by sex. To accommodate sensitivities, questions on sexual activity were not asked of minors (under 18 years). Field testing of interview procedures, survey logistics and the questionnaire was carried out in an urban area, a rural community, and a camp setting.

As the formative work indicated a lack of comfort or trust with computer assisted self-interview, interviewing was done face-to-face, with one partial exception. Youth initially had the option of taking a self-administered (paper) questionnaire for questions on sexual activity that retained the face-to-face format, but with the answers written rather than spoken aloud and then placed by the youth in a sealed envelope. Soon after the start of the fieldwork, the questionnaire was instead randomly allocated to ascertain if the mode mattered for responses, to be assessed in future work.

Youth consent/assent and (for minors) parental consent was obtained for the interviews. The study was approved by RAND's Human Subjects Protection Committee. Refusal rates among youth were low, $11 \%$ for the survey overall, and that partly reflects a high (about $30 \%$ ) refusal rate in East Jerusalem.

\section{Data analysis}

Analysis of group differences in behaviour by subgroups was done primarily using Pearson chi-squared tests. Separate analyses by sex were performed using STATA, version 13, and incorporating the 2-stage survey design, in particular to allow correlations of standard errors within sample clusters.

\section{Results}

\section{Sample characteristics}

Ultimately the sample consisted of 2481 youth with usable data. In keeping with the overall demographic profile of the occupied Palestinian territory, there are more individuals in the younger age group (15-19 years): $1419(57.2 \%)$ vs 1062 aged $20-24$ years (42.8\%) (Table 1 ). However, males aged 20-24 years make up only $40.0 \%$ of all males, while the older female group accounts for $45.7 \%$ of all females. This is likely explained by older male youths being more likely to be living away from home, or if living at home, being unavailable for interview even after several visits. About one quarter of the sample are classified as refugees (Table 2), that is, descendants of individuals who lost land or livelihood during the 1948 or 1967 conflicts. Most refugee families do not actually live in refugee camps, which can be rural or urban.

Youth in camps are less likely to be in school (Table 2 ), and have lower grade attainment. Among males aged $15-24$ years, while $60.4 \%$ of urban and $64.1 \%$ of rural respondents are in school, only $44.8 \%$ of those in camps are $(P=0.019$ and 0.006 for comparison of camps with urban and rural areas); the differences for females are smaller and not statistically significant $(P=0.253$ and 0.200). Rural respondents are less well-off than urban residents, as indicated by an asset index constructed from 


\begin{tabular}{|c|c|c|c|c|c|c|}
\hline \multirow[t]{2}{*}{ Location } & \multicolumn{3}{|c|}{ Males, age (years) } & \multicolumn{3}{|c|}{ Females, age (years) } \\
\hline & $15-19$ & $20-24$ & All & $15-19$ & $20-24$ & All \\
\hline \multicolumn{7}{|l|}{ Urban } \\
\hline Number & 490 & 321 & 811 & 433 & 377 & 810 \\
\hline Share (column) & 0.66 & 0.65 & 0.65 & 0.64 & 0.66 & 0.65 \\
\hline \multicolumn{7}{|l|}{ Rural } \\
\hline Number & 198 & 136 & 334 & 191 & 143 & 334 \\
\hline Share (column) & 0.27 & 0.27 & 0.27 & 0.28 & 0.25 & 0.27 \\
\hline \multicolumn{7}{|l|}{ Camp } \\
\hline Number & 58 & 38 & 96 & 49 & 47 & 96 \\
\hline Share (column) & 0.08 & 0.08 & 0.08 & 0.07 & 0.08 & 0.08 \\
\hline \multicolumn{7}{|l|}{ All } \\
\hline Number & 746 & 495 & 1241 & 673 & 567 & 1240 \\
\hline Share (column) & 1.00 & 1.00 & 1.00 & 1.00 & 1.00 & 1.00 \\
\hline Share (row) & 0.30 & 0.20 & 0.50 & 0.27 & 0.23 & 0.50 \\
\hline
\end{tabular}

data on consumer durables $(13)(P=0.001$ and $P \leq 0.001$ for males and females respectively). The index appears lowest for camp residents, but the study lacks power for detecting differences between camps and the other areas.

\section{Health risk behaviours}

\section{Response rates}

Non-response rates ("no answer" or "don't know") on individual questions were generally very low, under 1\%. Rates were somewhat higher (though under 5\%) for questions on current drug use asked of those who indicated that they had tried drugs.

\section{Smoking}

Prevalence of all health risk behaviours are shown in Table 3. With respect to tobacco use, $71.5 \%$ of older male youth report current smoking (cigarettes or waterpipe) while $45.4 \%$ of younger male youth do. Rates are lower for females but still significant: $31.2 \%$ for older and $21.6 \%$ for younger females $(P \leq 0.001$ for male-female difference for both age groups). Tobacco use is lower in rural compared with urban areas.

There are also age as well as gender differences for use of cigarettes compared with waterpipe (not shown in table). Among youth who use any tobacco, cigarette smoking becomes more important with age. For example, among male youth who smoke, the proportion reporting cigarette use increases from 69\% for ages 15-19 years to $83 \%$ for ages $20-24$ years, while waterpipe use declines from $54 \%$ to $42 \%$ (the percentages sum to more than $100 \%$ since about one-quarter of male smokers in both age groups use both cigarettes and waterpipe). This increase with age in the predominance of cigarette smoking holds for female smokers too, but waterpipe is substantially more common overall for females: even among older female smokers $20-24$ years, only $41 \%$ smoke cigarettes while $70 \%$ use waterpipe.

\section{Alcohol use}

Among male youth aged 20-24 years, 22.4\% reported having tried alcohol; rates in urban areas and camps (around 26\% each) are double that in rural areas $(13.2 \% ; P=$ 0.002 and 0.039 , for comparison of rural with urban areas and camps) (Table 3). Rates among female youth aged 2024 years are substantially lower, but with a similar pattern by area (14.6\% in urban areas, $12.8 \%$ in camps, and $3.5 \%$ in rural areas). Among youth aged $15-19$ years, $8.0 \%$ of males and $3.6 \%$ of females reported ever trying alcohol, again with higher shares in urban areas and camps. Slightly less than $10 \%$ of older male youth and $3.4 \%$ of younger male youth reported current alcohol consumption (the last 30 days), compared with $4.1 \%$ of older females and $1.2 \%$ of younger females.

\section{Drug use}

Among males aged 20-24 years, 10.5\% reported having tried any kind of drugs, including marijuana or hashish, pills, inhalants and cocaine or heroin compared with $3.75 \%$ for younger male youth (Table 3 ). Only $4.2 \%$ of older female youth and $1.6 \%$ of younger female youth reported ever using drugs. As with alcohol, self-reported drug use is markedly higher in urban areas and camps than in rural areas. The most common drugs tried are marijuana/ hashish (57\%), inhalants (42\%) and pills (14\%). Among those who had tried drugs, about one-third of both the younger and older male youth said they currently used drugs of some kind; for females who had ever tried drugs, $29.2 \%$ of those aged $20-24$ years and $9.1 \%$ of those aged 15-19 years said they currently use them. This implies that about $3.6 \%$ of all older male youth and $1.1 \%$ of younger male youth, and $1.2 \%$ of older females and $0.2 \%$ of younger females currently use drugs.

\section{Sexual activity}

Around $25 \%$ of older (20-24 years) unmarried male youth and just over $20 \%$ of younger non-minor (18-19 


\begin{tabular}{|c|c|c|c|c|c|c|}
\hline \multirow[t]{2}{*}{ Characteristic } & \multicolumn{3}{|c|}{ Males, age (years) } & \multicolumn{3}{|c|}{ Females, age (years) } \\
\hline & All & $15-19$ & $20-24$ & All & $15-19$ & $20-24$ \\
\hline No. of observations & 1241 & 746 & 495 & 1240 & 673 & 567 \\
\hline Years of schooling & 11.3 & 10.5 & 12.4 & 11.9 & 10.9 & 13.2 \\
\hline Refugee & $25.4 \%$ & $23.1 \%$ & $28.9 \%$ & $26.4 \%$ & $27.0 \%$ & $25.6 \%$ \\
\hline \multicolumn{7}{|l|}{ Currently in school } \\
\hline All & $60.2 \%$ & $78.7 \%$ & $32.3 \%$ & $64.8 \%$ & $85.3 \%$ & $40.4 \%$ \\
\hline Urban & $60.4 \%$ & $79.8 \%$ & $30.8 \%$ & $64.8 \%$ & $85.9 \%$ & $40.6 \%$ \\
\hline Rural & $64.1 \%$ & $81.3 \%$ & $39.0 \%$ & $66.5 \%$ & $84.3 \%$ & $42.7 \%$ \\
\hline Camp & $44.8 \%$ & $60.3 \%$ & $21.1 \%$ & $58.3 \%$ & $83.7 \%$ & $31.9 \%$ \\
\hline \multicolumn{7}{|l|}{ Married } \\
\hline All & $2.6 \%$ & $0.0 \%$ & $6.5 \%$ & $22.3 \%$ & $4.6 \%$ & $43.4 \%$ \\
\hline Urban & $3.0 \%$ & $0.0 \%$ & $7.5 \%$ & $22.5 \%$ & $4.6 \%$ & $43.0 \%$ \\
\hline Rural & $1.5 \%$ & $0.0 \%$ & $3.7 \%$ & $21.9 \%$ & $4.2 \%$ & $45.5 \%$ \\
\hline Camp & $3.1 \%$ & $0.0 \%$ & $7.9 \%$ & $22.9 \%$ & $6.1 \%$ & $40.4 \%$ \\
\hline \multicolumn{7}{|l|}{ Working } \\
\hline Yes & $31.0 \%$ & $16.1 \%$ & $53.5 \%$ & $6.0 \%$ & $1.0 \%$ & $12.0 \%$ \\
\hline \multicolumn{7}{|l|}{ Living arrangement } \\
\hline With parents & $96.8 \%$ & $98.9 \%$ & $93.5 \%$ & $78.7 \%$ & $94.9 \%$ & $59.4 \%$ \\
\hline With spouse in own household & $2.1 \%$ & $0.0 \%$ & $5.3 \%$ & $17.7 \%$ & $3.6 \%$ & $34.6 \%$ \\
\hline Other $^{\mathrm{a}}$ & $0.6 \%$ & $0.7 \%$ & $0.6 \%$ & $3.1 \%$ & $1.2 \%$ & $5.3 \%$ \\
\hline \multicolumn{7}{|c|}{ Father's education (secondary or higher) } \\
\hline Urban & $56.2 \%$ & $58.2 \%$ & $53.3 \%$ & $47.7 \%$ & $54.0 \%$ & $40.3 \%$ \\
\hline Rural & $59.6 \%$ & $63.1 \%$ & $54.4 \%$ & $59.0 \%$ & $62.3 \%$ & $54.5 \%$ \\
\hline Camp & $49.0 \%$ & $50.0 \%$ & $47.4 \%$ & $43.8 \%$ & $44.9 \%$ & $42.6 \%$ \\
\hline \multicolumn{7}{|c|}{ Mother's education (secondary or higher) } \\
\hline Urban & $53.1 \%$ & $59.2 \%$ & $43.9 \%$ & $45.6 \%$ & $51.5 \%$ & $38.7 \%$ \\
\hline Rural & $47.6 \%$ & $49.0 \%$ & $45.6 \%$ & $40.7 \%$ & $47.6 \%$ & $31.5 \%$ \\
\hline Camp & $45.8 \%$ & $51.7 \%$ & $36.8 \%$ & $40.6 \%$ & $40.8 \%$ & $40.4 \%$ \\
\hline Asset index & \multicolumn{6}{|c|}{ Index value } \\
\hline Urban & 0.23 & 0.24 & 0.21 & -0.01 & -0.01 & -0.01 \\
\hline Rural & -0.06 & -0.07 & -0.03 & -0.32 & -0.28 & -0.39 \\
\hline Camp & -0.08 & -0.07 & -0.10 & -0.40 & -0.28 & -0.52 \\
\hline
\end{tabular}

aIncludes: "live with my spouses' parent(s)", "live with other relatives" and zlive with friends".

years) unmarried male youth reported having had sexual activity, defined as "romantic kissing, touching private body parts, or sexual intercourse" (Table 3). Male-female differences are not statistically significant $(P=0.432$ for younger males vs younger females, 0.288 for older males vs older females). Rural-urban differences appear pronounced for males: for older males, the shares are $27.4 \%$ in urban areas, $14.5 \%$ in rural areas, and $38.2 \%$ in camps $(P=0.030$ for urban vs rural; $P=0.292$ for urban vs camps for this group).

Experience of sexual intercourse specifically is substantially lower. Among unmarried males, 9.5\% of older (20-24 years) youth and $5-6 \%$ of younger (18-19 years) youth reported having had sexual intercourse. Corresponding shares are $6.9 \%$ for older females and $4.1 \%$ for younger females. Male-female differences are not statistically significant, but rates of sexual intercourse experience are markedly lower in rural areas than urban areas and camps.

Phone sex (sexting) and internet sex (defined as interaction with another person, not merely viewing sexual material) among unmarried youth of both sexes is more common than self-reported physical sexual contact: $38.0 \%$ of older and $33.3 \%$ of younger (18-19 years) males reported having ever engaged in either phone or internet sex; $29.6 \%$ of older female youth and $23.4 \%$ of those aged 18-19 years reported having done so.

\section{Interpersonal violence}

Among youth aged $15^{-19}$ years, $56.0 \%$ of males and $29.3 \%$ of females reported engaging in a physical fight with someone in the last year (Table 3). Among those aged 


\begin{tabular}{|c|c|c|c|c|c|c|c|c|}
\hline \multirow[t]{2}{*}{ Behaviour \& age group (years) } & \multicolumn{4}{|c|}{ Males (\%) } & \multicolumn{4}{|c|}{ Females (\%) } \\
\hline & All & Urban & Rural & Camps & All & Urban & Rural & Camps \\
\hline \multicolumn{9}{|l|}{ Current smoking } \\
\hline $15-19$ & 45.4 & 46.5 & 41.9 & 48.3 & 21.5 & 26.8 & 9.9 & 20.4 \\
\hline $20-24$ & 71.5 & 77.6 & 56.6 & 73.7 & 31.2 & 36.6 & 16.1 & 34.0 \\
\hline All & 55.8 & 58.8 & 47.9 & 58.3 & 26.0 & 31.4 & 12.6 & 27.1 \\
\hline \multicolumn{9}{|l|}{ Ever used alcohol } \\
\hline $15-19$ & 8.0 & 9.8 & 4.0 & 6.9 & 3.6 & 4.6 & 1.0 & 4.1 \\
\hline $20-24$ & 22.4 & 25.9 & 13.2 & 26.3 & 11.6 & 14.6 & 3.5 & 12.8 \\
\hline All & 13.8 & 16.2 & 7.8 & 14.6 & 7.3 & 9.3 & 2.1 & 8.3 \\
\hline \multicolumn{9}{|l|}{ Current alcohol use } \\
\hline $15-19$ & 3.4 & 4.5 & 0.5 & 3.4 & 1.2 & 1.8 & 0.0 & 0.0 \\
\hline $20-24$ & 9.1 & 11.2 & 3.7 & 10.5 & 4.1 & 5.0 & 1.4 & 4.3 \\
\hline All & 5.6 & 7.2 & 1.8 & 6.3 & 2.5 & 3.3 & 0.6 & 2.1 \\
\hline \multicolumn{9}{|l|}{ Ever used drugs } \\
\hline $15-19$ & 3.8 & 4.3 & 2.0 & 5.2 & 1.6 & 1.8 & 0.5 & 4.1 \\
\hline $20-24$ & 10.5 & 13.1 & 2.9 & 15.8 & 4.2 & 5.3 & 0.7 & 6.4 \\
\hline \multicolumn{9}{|l|}{$\begin{array}{l}\text { Current drug use (as \% of those who } \\
\text { ever use drugs) }\end{array}$} \\
\hline $15-19$ & 32.1 & 33.3 & 50.0 & 0.0 & 9.1 & 12.5 & 0.0 & 0.0 \\
\hline $20-24$ & 34.6 & 38.1 & 25.0 & 16.7 & 29.2 & 35.0 & 0.0 & 0.0 \\
\hline \multicolumn{9}{|l|}{$\begin{array}{l}\text { Had any sexual activity (unmarried, } \\
\text { aged } \geq 18 \text { years) }\end{array}$} \\
\hline $15-19$ & 21.5 & 23.9 & 10.3 & 35.0 & 24.9 & 27.6 & 19.6 & 16.7 \\
\hline $20-24$ & 24.5 & 27.4 & 14.5 & 38.2 & 20.9 & 21.9 & 21.8 & 10.7 \\
\hline \multicolumn{9}{|l|}{$\begin{array}{l}\text { Had sexual intercourse (unmarried, } \\
\text { aged } \geq 18 \text { years) }\end{array}$} \\
\hline $15-19$ & 5.5 & 6.9 & 1.7 & 5.0 & 4.1 & 4.5 & 2.0 & 8.3 \\
\hline $20-24$ & 9.3 & 12.2 & 2.3 & 11.8 & 6.9 & 8.8 & 2.6 & 3.6 \\
\hline \multicolumn{9}{|l|}{$\begin{array}{l}\text { Had internet or phone sex } \\
\text { (unmarried, aged } \geq 18 \text { years) }\end{array}$} \\
\hline $15-19$ & 33.3 & 32.7 & 32.8 & 40.0 & 23.4 & 26.1 & 15.7 & 25.0 \\
\hline $20-24$ & 38.0 & 41.6 & 27.5 & 47.1 & 29.6 & 32.6 & 20.5 & 32.1 \\
\hline All & 36.4 & 38.5 & 29.1 & 44.4 & 27.2 & 30.1 & 18.6 & 30.0 \\
\hline \multicolumn{9}{|l|}{ Engaged in a fight last year } \\
\hline $15-19$ & 56.0 & $57 \cdot 3$ & 53.0 & 55.2 & 29.3 & 30.5 & 24.1 & 38.8 \\
\hline $20-24$ & 38.4 & 41.4 & 30.1 & 42.1 & 21.0 & 24.7 & 10.5 & 23.4 \\
\hline All & 49.0 & 51.1 & 43.7 & 50.0 & 25.5 & 27.8 & 18.3 & 31.3 \\
\hline \multicolumn{9}{|l|}{ Ever hurt or injured in a fight } \\
\hline $15-19$ & 31.0 & 33.7 & 26.8 & 22.4 & 16.8 & 17.8 & 14.1 & 18.4 \\
\hline $20-24$ & 26.7 & 26.5 & 24.3 & 36.8 & 13.6 & 16.2 & $7 \cdot 7$ & 10.6 \\
\hline All & 29.3 & 30.8 & 25.8 & 28.1 & 15.3 & 17.0 & 11.4 & 14.6 \\
\hline \multicolumn{9}{|l|}{ Ever hurt or injured someone else } \\
\hline $15-19$ & 40.8 & 43.3 & 33.8 & 43.1 & 14.1 & 14.8 & 11.0 & 20.4 \\
\hline $20-24$ & 36.6 & 37.4 & 30.9 & 50.0 & 11.8 & 14.3 & 4.9 & 12.8 \\
\hline All & 39.1 & 40.9 & 32.6 & 45.8 & 13.1 & 14.6 & 8.4 & 16.7 \\
\hline
\end{tabular}


$20-24$ years, $38.4 \%$ of males and $21.0 \%$ of females reported have been in a fight $(P \leq 0.001$ for males vs females in both age groups). Among all youth reporting any fighting, $42 \%$ report 1 incident in the last year, with most of the rest reporting 2-5 incidents. For both age groups there is higher prevalence in urban areas than rural $(P=0.049$ for urban vs rural for younger youth, $P \leq 0.001$ for older youth).

\section{Self-reported own behaviours and perceived behaviours of peers' compared}

Responses about risk behaviours of close friends as well as general peers (youth of the respondent's age and sex in their communities) suggest higher mean levels of risk behaviour among friends and peers than respondents' own levels of these behaviours, while showing similar patterns across age, sex and location (Table 4). The differences between reported own and general peers' behaviours are especially large. For example, $9.1 \%$ of male youth aged 20-24 years say they currently drink (Table 3) compared with their perceptions of $13.0 \%$ for friends $(P$ $<0.001$ ) and $22.5 \%$ for general peers (Table 4). For young women in this age group, reported current drinking is $4.1 \%$ compared with perceptions of $6.7 \%$ and $10.9 \%$ for friends and general peers, respectively. A similar pattern is seen for other risk behaviours.

\section{Discussion}

\section{Levels of risk behaviour in international perspective}

This study is the first to collect population-based data on Palestinian-and perhaps any Middle Eastern-youth on a comprehensive range of health risk behaviours. Comparisons with studies from other regions are therefore of particular interest. These comparisons, discussed in detail elsewhere (13), show the prevalence of most self-reported risk behaviours in our sample of youth to be at the low end of the range of findings from countries in other regions, likely reflecting the conservative social context of this study. In the United States of America (USA), self-reported drinking was $34 \%$ for boys and 36\% for girls aged $13-18$ years (14), and $41 \%$ and $30 \%$ in South Africa for boys and girls aged 14-18 years (15) compared with $3.4 \%$ of boys and $1.2 \%$ of girls aged $15-19$ years in our sample. More in line with our findings, in Tehran (Islamic Republic of Iran) $17 \%$ of boys aged $13-18$ years reported trying alcohol (16) ( $8 \%$ of males in our sample aged 15-19 years reported doing so). Comparisons for drug use and sexual activity reveal a similar pattern of relatively low rates in the occupied Palestinian territory (10).

However, Palestinian youth show comparatively very high levels of smoking. Even among younger youth aged

\begin{tabular}{|c|c|c|c|c|c|c|c|c|}
\hline \multirow[t]{2}{*}{ Behaviour $\&$ age group (years) } & \multicolumn{4}{|c|}{ Males (\%) } & \multicolumn{4}{|c|}{ Females (\%) } \\
\hline & All & Urban & Rural & Camps & All & Urban & Rural & Camps \\
\hline \multicolumn{9}{|l|}{ Current smoking } \\
\hline 15-19 (friends) & 54.1 & 53.4 & 52.2 & 66.1 & 16.9 & 18.7 & 11.5 & 21.5 \\
\hline 15-19 (peers) & 64.0 & 63.7 & 60.3 & 79.2 & 20.1 & 23.2 & 10.6 & 28.5 \\
\hline $20-24$ (friends) & 76.4 & 77.0 & 72.1 & 86.8 & 27.6 & 32.7 & 13.1 & 31.2 \\
\hline $20-24$ (peers) & 80.4 & 80.5 & 78.8 & $85 \cdot 3$ & 28.8 & 34.1 & 11.7 & 39.1 \\
\hline \multicolumn{9}{|l|}{ Current alcohol use } \\
\hline 15-19 (friends) & 6.4 & 7.3 & 3.7 & 8.2 & 1.9 & 2.6 & 0.7 & 0.7 \\
\hline 15-19 (peers) & 13.0 & 13.4 & 10.9 & 17.3 & 5.5 & 7.4 & 1.1 & 7.1 \\
\hline 20-24 (friends) & 13.0 & 15.3 & 7.2 & 14.9 & 6.7 & 8.2 & 2.3 & 8.0 \\
\hline 20-24 (peers) & 22.5 & 25.1 & 15.2 & 25.5 & 10.9 & 13.3 & 3.1 & 15.2 \\
\hline \multicolumn{9}{|l|}{ Current drug use } \\
\hline 15-19 (friends) & 1.0 & 1.2 & 0.0 & 2.9 & 0.2 & 0.3 & 0.2 & 0.0 \\
\hline $15^{-19}$ (peers) & 7.6 & 8.5 & 3.8 & 12.7 & 4.2 & 5.6 & 0.5 & 6.3 \\
\hline 20-24 (friends) & 4.0 & 5.1 & 1.2 & 4.4 & 2.1 & 2.6 & 0.7 & 2.9 \\
\hline 20-24 (peers) & 13.2 & 15.2 & 8.5 & 12.1 & 8.1 & 10.1 & 1.0 & 14.0 \\
\hline \multicolumn{9}{|l|}{$\begin{array}{l}\text { Current sexual activity, unmarried } \\
\text { (intercourse) }\end{array}$} \\
\hline 15-19 (friends) & 4.2 & 4.0 & 4.7 & 4.2 & 9.8 & 8.9 & 10.7 & 14.1 \\
\hline 15-19 (peers) & 7.7 & 7.7 & 7.0 & 9.3 & 10.6 & 12.4 & $5 \cdot 3$ & 17.3 \\
\hline 20-24 (friends) & 11.8 & 13.6 & 7.4 & 13.1 & 20.8 & 22.2 & 16.1 & 26.0 \\
\hline 20-24 (peers) & 14.1 & 15.4 & 11.7 & 11.8 & 15.2 & 18.4 & 5.1 & 20.0 \\
\hline
\end{tabular}

"Friends" refers to the 3 closest friends of the respondent; \% for each respondent is calculated as the number reported to engage in the behaviour divided by 3.

"Peers" refers to general peers in the community of the same age and sex of the respondent. 
15-19 years, $45 \%$ of males and $22 \%$ of females aged $15^{-19}$ years reported smoking in our survey. Tobacco use among young Palestinians is well above the average for countries in the Eastern Mediterranean Region based on crosscountry Global Youth Tobacco Surveys of 13-15-year-olds (17), and has aptly been characterized as an epidemic (6). Levels of interpersonal violence also appear high, comparable to findings among South African secondary students, of whom $39 \%$ of boys and $25 \%$ of girls reported being in a fight in the last 6 months (15); our findings for male and female youth aged 15-19 years over a reference period that is twice as long, are $56 \%$ and $29 \%$, respectively. In the USA participation in fighting is lower: $30.2 \%$ for males and $19.2 \%$ for females among secondary students during the last 12 months (14).

\section{Assessment of validity of self-reports}

The survey relies on what youth report to interviewers about their behaviours, not objective measures of these behaviours. Despite efforts to ensure that respondents felt comfortable answering sensitive questions, underreporting of risk behaviours in this conservative environment remains an important potential limitation of this study. In this regard, it is noteworthy that, as seen earlier, responses about peers, especially general peers, suggest mean levels of risk behaviour substantially higher than implied by responses about the respondent's own behaviour. Studies from the USA and elsewhere find similar disparities between descriptive peer norms and self-reported alcohol and drug use (18-20). This divergence is due either to underreporting of one's own behaviour or overestimating (or over-reporting) peers' engagement, or both. The fact that respondents' estimates of close friends' engagement in risk behaviours, which they should know fairly accurately, are lower than their estimates for general peers suggests that general peers' engagement may be overestimated. However, youth may also understate friends' behaviour (as with their own) if they believe socially undesirable behaviour of friends reflects badly on them. Research using biomarkers suggests underreporting of own drug use in the USA (21).

Since the potential bias in self-reported behaviour will likely be downward, and any bias with respect to peers' activities is expected to be upward, these 2 estimates likely bound the true prevalence of a behaviour. This range suggests that prevalence of most health risk behaviours is still modest but not trivial (and is high for smoking and engaging in violent behaviour).

\section{Patterns across subgroups}

Engagement in risk behaviours is consistently higher for male youth, for older youth and in urban areas and refugee camps (compared with rural areas). Rural location may inhibit engagement because drugs and alcohol are less available, cultural stigma is higher and it is harder to be discrete or anonymous in a village setting. Although the study was not powered to detect variation across urban areas, the data suggest substantial variation here as well; in particular, Jerusalem stands out for its high prevalence of youth alcohol use, drug use and sexual activity (13). This governorate consists of J1 area (East Jerusalem), annexed by Israel in 1980, and J2, mostly urban areas that formally remain in the West Bank. In addition to close access to drugs or alcohol from Israel, several factors may contribute to the high levels of risk behaviours in these areas. East Jerusalem is marked by economic depression, poor social services and significant social and political tensions while many parts of J2 are essentially not covered by either Israeli or Palestinian law enforcement authorities, permitting the development of a thriving drug trade $(22,23)$.

Regarding sexual activity, while experience of sexual intercourse among unmarried youth seems rare, sexual activity overall is not. Phone and internet sex are fairly common for both sexes and among both older and younger youth. These forms of interaction pose no direct health risk; the question is whether they are a substitute for actual sexual contact, which is harder for young people to arrange discreetly, or a complement to (or a determinant of) physical sexual relations. For both young men and young women, there is a statistically significant positive association of sexting/internet sex with having had intercourse. Future research will attempt to assess whether this relationship is causal.

\section{Conclusion}

The experience of the Palestinian Youth Health Risk study demonstrates that it is possible to carry out populationbased surveys of youth on highly sensitive behaviours in conservative contexts of the Middle East. Given the lack of systematic information on these behaviours in the region, similar surveys should be carried out elsewhere, both to understand current prevalence and monitor changes over time.

Outreach and risk prevention programmes for Palestinian youth are relatively undeveloped, as they are in the region generally (24). Our findings provide some guidance as to where such programmes should be targeted. Male youth, especially older ones, are the most likely to engage in health risk activities. Programmes should therefore make particular efforts to engage male youth, but should not ignore female youth, who also engage in these behaviours, if to a lesser extent. Urban youth and those in camps (many of which are essentially low-income urban neighbourhoods) are clearly at greater risk for these behaviours and this should be reflected in outreach efforts. Of particular concern for programming for all groups of youth are high levels of tobacco use, which has clear long-term health implications. Interpersonal violence also appears high and should be of concern to policymakers; in addition to direct health impacts through injury, it may lead to significant negative emotional outcomes. The data also confirm the need to address waterpipe use among younger Palestinian youth. Waterpipe smoking, which has been rising sharply in the region in the last several decades, is associated with a range of diseases and may act as a gateway to cigarette smoking (25). 
Regarding the kinds of prevention programmes that would be most effective, currently there are few models from the region of programmes that have been rigorously tested and/or scaled up. With careful consideration of the specific MENA context-including high levels of stigma and the need to reach older youth who have left school-experience from industrialized nations and other regions can provide guidance $(26,27)$. For example, with regard to tobacco use, in addition to education, price increases as well as advertising bans have been shown to reduce youth smoking in other contexts $(28,29)$. Further, a substantial body of global research shows that behavioural smoking cessation interventions increase the likelihood of quitting and long-term smoking abstinence, including among youth $(30,31)$. However, there have been few rigorously tested applications in the region. In the area of sexual and reproductive health programming for youth, some programmes have been introduced in MENA countries. These include peer (youth-to-youth) education programmes such as the Youth Peer Education Network implemented in Tunisia and other countries; anonymous telephone hotlines to make information readily accessible confidentially; and the use of social media for youth-friendly discussion and education $(4,24)$. Each of these has the potential, among other benefits, to be able to reach out-of-school youth.

Evaluation of a range of prevention approaches to youth risk behaviour in the occupied Palestinian territory and elsewhere in the region are needed, as is more effort to monitor risk behaviours, which can inform these efforts. Future work with the present data will investigate the determinants of risk behaviours, including for example exposure to violence, mental health and assessment of risks, and thus provide additional guidance to the development of prevention programmes for Palestinian youth.

Funding: Research reported in this article was supported by the National Institute of Child Health and Human Development of the U.S. National Institutes of Health under award number Ro1HDo67115-03. The content is solely the responsibility of the authors and does not necessarily represent the official views of the National Institutes of Health.

Competing interests: None declared.

\section{Comportements à risque pour la santé chez les jeunes palestiniens : résultats d'une étude représentative}

\section{Résumé}

Contexte : Il existe peu de données systématiques sur les comportements à risque pour la santé chez les jeunes au Moyen-Orient. Les autorités de santé publique ne sont donc pas préparées aux menaces de santé publique émergentes en période de changement social majeur.

Objectif : L'Étude des risques sanitaires chez les jeunes palestiniens examine les schémas comportementaux à risque parmi les jeunes palestiniens, leurs perceptions des risques et des bénéfices tirés de tels comportements, la relation entre l'exposition à la violence et la santé mentale, et l'adoption de comportements à risque.

Méthodes : Nous avons réalisé une enquête représentative auprès de 2500 individus âgés de 15 à 24 ans en Cisjordanie et à Jérusalem-Est, ce qui nous a permis de procéder à une comparaison fiable en fonction du sexe ainsi qu'entre zones rurale et zones urbaines. Un échantillon aléatoire stratifié à deux niveaux a été prélevé dans le recensement de population de 2007, avec des strates formées en sélectionnant les zones urbaines, rurales, et les camps de réfugiés au sein des 12 gouvernorats. Dans les strates, 208 foyers d'étude ont été échantillonnés, avec une probabilité proportionnelle à la taille. Au sein de chaque foyer, 14 ménages comptant des jeunes ayant l'âge approprié ont été échantillonnés.

Résultats : Parmi les jeunes âgés de 20 à 24 ans, $22,4 \%$ des garçons et 11,6\% des filles ont rapporté avoir déjà essayé l'alcool, et 10,5\% des garçons et 4,3\% des filles ont signalé avoir déjà essayé les drogues. Près d'un quart des jeunes célibataires âgés de 20 à 24 ans ont rapporté n'avoir eu aucune expérience sexuelle. Le tabagisme est très élevé, même chez les plus jeunes (45,4\% des garçons et $21,2 \%$ des jeunes filles âgés de 15 à 19 ans fument). Les comportements à risque sont plus élevés parmi les garçons, chez les jeunes plus âgés, dans les zones urbaines et dans les camps de réfugiés.

Conclusion : Si le tabagisme est particulièrement préoccupant, des activités de prévention pour l'ensemble des comportements devraient être menées dans les sous-groupes et les zones identifiés à haut risque.

$$
\begin{aligned}
& \text { السلو كيات التي تنطوي على مخاطر صحية بين الشباب الفلسطينيين: نتائج مستمدة من مسح تمثيلي } \\
& \text { بيتر جليك، أمية الخحاش، محمد شاهين، رايان براون، بروديومنا جو تام، ريتا كرم، سيباستيان لينياير، سلوى مسعد لئل } \\
& \text { الخلاصة: } \\
& \text { الخلفية: لا تتوفر سوى معلومات منهجية ضئيلة عن كثير من السلوكيات التي تنطوي على مخاطر صحية بين شباب الشرق الأوسط. }
\end{aligned}
$$




$$
\begin{aligned}
& \text { الهدف: توفّر هذه الدراسة تقديرات لمستويات وأنماط السلوكيات الخطرة بين الشباب الفلسطينيين استناداً إلى مسح ذو طابع تمثيلي واسع النطاق. }
\end{aligned}
$$

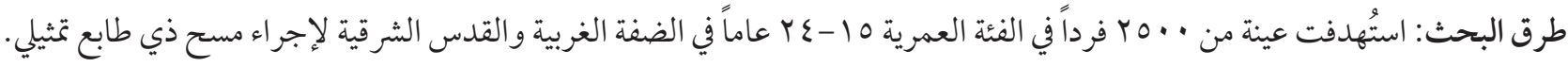

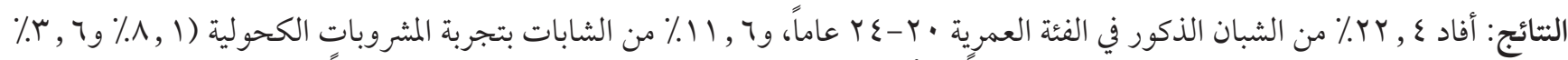

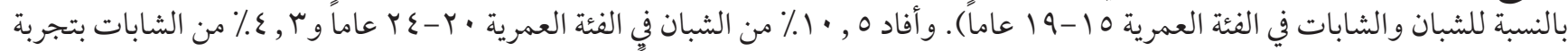

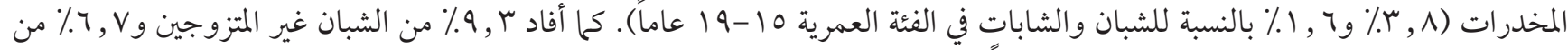

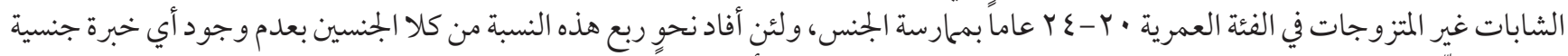

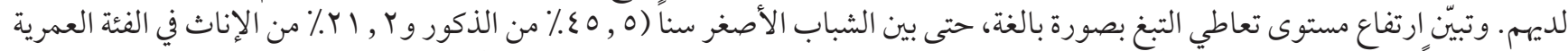

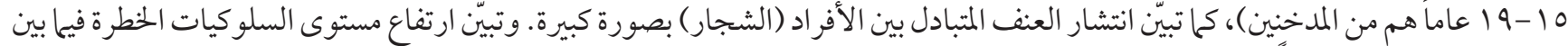

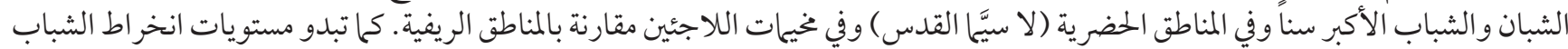

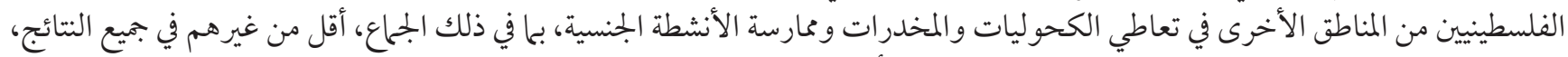

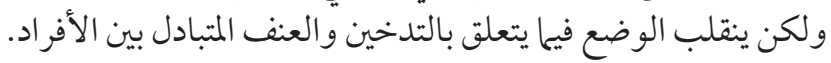

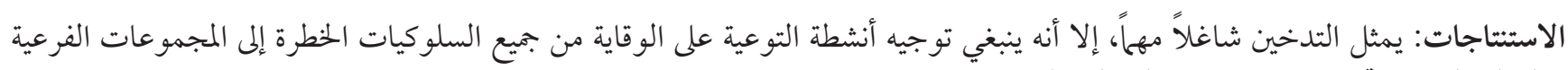

$$
\begin{aligned}
& \text { و المناطق التي يتم تحديدها باعتبارها عالية المخاطر. }
\end{aligned}
$$

\section{References}

1. Progress for children: A report card on adolescents. New York: United Nations Children's Fund; 2012.

2. Roudi-Fahimi F. Time to intervene: preventing the spread of HIV/AIDS in the Middle East and North Africa. Washington, DC: Population Reference Bureau; 2007.

3. United Nations Office on Drugs and Crime. World drug report 2016. New York: United Nations; 2016.

4. Shepard BL, DeJong JL. Breaking the silence: young people's sexual and reproductive health in the Arab States and Iran. Boston: Harvard School of Public Health; 2005.

5. Jenkins C, Robalino D. Overview of the HIV/AIDS situation in the Middle East and North Africa and Eastern Mediterranean region. Why waiting to intervene can be costly. Washington DC: World Bank; 2003.

6. Husseini A, Abu-Rmeileh N, Mikki N, Ramahi T, Ghosh H, Barghuthi N, et al. Smoking and associated factors in the occupied Palestinian territory. Birzeit: Institute of Community and Public Health, Birzeit University; 2010.

7. Ghrayeb FA, Mohamed Rusli A, Al Rifai A, Mohd Ismail I. Youth in trouble: tobacco use among school students in Palestine. Canadian J Basic Applied Sciences. 02)01;2013):67-58.

8. International Narcotics Control Board. Report of the international narcotics control board for 2007. New York: United Nations; 2008.

9. Morrell SL, Taylor RJ, Kerr CB. Jobless: unemployment and young people's health. Med J Aust. 5)168;1998):40-236. PMID:9539904

10. Peck DF, Plant MA. Unemployment and illegal drug use: concordant evidence from a prospective study and national trends. Br Med J (Clin Res Ed). 6552)293;1986):32-929. PMID:3094720

11. Press release on the Labour Force Survey Results (January-March, 2010) (Q2010/1). Ramallah, Palestine: Palestinian Central Bureau of Statistics; 2010.

12. Akala FA. Preventing HIV/AIDS in the Middle East and North Africa: a window of opportunity to act. Washington, DC: The World Bank; 2005.

13. Glick P, Kammash U, Shaheen M, Brown RA, Goutam P, Karam R, et al. Prevalence and patterns of health risk behaviors of Palestinian youth: Findings from a representative survey. Santa Monica: RAND Corporation; 2016 (Contract No.: WR-1119).

14. Kann L, Kinchen S, Shanklin SL, Flint KH, Kawkins J, Harris WA, et al. Youth risk behavior surveillance-United States, 2013. MMWR Suppl. 4)63;2014):168-1. PMID:24918634

15. National Health Promotion Research and Development Group. The 2nd South African youth risk behaviour survey, 2008, Umthente, Uhlaba, Usamila. Cape Town: South Africa Medical Research Council; 2010.

16. Mohammadi MR, Mohammad K, Farahani FK, Alikhani S, Zare M, Tehrani FR, et al. Reproductive knowledge, attitudes and behavior among adolescent males in Tehran, Iran. Int Fam Plan Perspect. 44-2006:35. PMID:16723300

17. Usmanova G, Mokdad AH. Results of the Global Youth Tobacco Survey and implementation of the WHO Framework Convention on Tobacco Control in the WHO Eastern Mediterranean Region (EMR) countries. J Epidemiol Glob Health. 4)3;2013):34-217. PMID:24206793

18. Perkins HW. College student misperceptions of alcohol and other drug norms among peers: exploring causes, consequences, and implications for prevention programs. Designing alcohol and other drug prevention programs in higher education: bringing theory into practice. Newton, Massachusetts: The Higher Education Center for Alcohol and Other Drug Prevention; -1997:177 206. 
19. Perkins HW, Berkowitz AD. Perceiving the community norms of alcohol use among students: some research implications for campus alcohol education programming. Int J Addict. 10-9)21;1986):76-961. PMID:3793315

20. Borsari B, Carey KB. Peer influences on college drinking: a review of the research. J Subst Abuse. 4)13;2001):424-391. PMID:11775073

21. Delaney-Black V, Chiodo LM, Hannigan JH, Greenwald MK, Janisse J, Patterson G, et al. Just say “I don't": lack of concordance between teen report and biological measures of drug use. Pediatrics. 5)126;2010):93-887. PMID:20974792

22. Monks K. East Jerusalem suffers heroin plague: Activists fight to save addicts in towns without prospects or security. Al Jazeera, 6 July 2011 (http://www.aljazeera.com/indepth/features/201162874544676539/06/2011.html, accessed 20 February 2018).

23. United Nations Office for the Coordination of Humanitarian Affairs, occupied Palestinian territory. East Jerusalem: key humanitarian concerns. East Jerusalem: United Nations; 2011.

24. Roudi-Fahimi F, El Feki S. Facts of life: youth sexuality and reproductive health in the Middle East and North Africa. Washington, DC: Population Reference Bureau; 2011 (http://www.prb.org/pdf11/facts-of-life-youth-in-middle-east.pdf, accessed 19 January 2018).

25. Kheirallah KA, Veeranki SP, Alzyoud S, Alzoubi A, Walker L, Khader Y, et al. Collision of waterpipe and cigarette smoking epidemics among youth in Arab countries. J Substance Use. 5)21;2016):6-530.

26. Lule E, Rosen J, Singh S, Knowles JC, Behrman JR. Adolescent health programs. In: Jamison DT, Berhman JR, Measham AR, Alleyne G, Claeson, M, Evans DB, et al, eds. Disease control priorities in developing countries, 2nd ed. Washington, DC: Oxford University Press and World Bank; 2006.

27. Manlove J, Fish H, Moore KA. Programs to improve adolescent sexual and reproductive health in the US: a review of the evidence. Adolesc Health Med Ther. 79-6:47;2015. PMID:25897271

28. Tobin S, Yach D. Trends and affordability of cigarette prices: ample room for tax increases and related health gains. Tob Control. 1)11;2002):43-35. PMID:11891366

29. Kostova D, Ross H, Blecher E. Markowitz S. Prices and cigarette demand: evidence from youth tobacco use in developing countries. Cambridge, Massachusetts: National Bureau of Economic Research; 2010 (Working Paper 15781; https://www.nber.org/ papers/w15781.pdf, accessed 19 January 2018).

30. Sussman S, Sun P, Dent CW. A meta-analysis of teen cigarette smoking cessation. Health Psychology. 57-25:549;2006. DOI:6133.25.5.549-0278/10.1037

31. Suls JM, Luger TM, Curry SJ, Mermelstein RJ, Sporer AK, An LC. Efficacy of smoking-cessation interventions for young adults: a meta-analysis. Am J Prev Med. 6)42;2012):62-655. PMID:22608385 